\title{
モデル計算法による杖歩行の評価
}

\section{Evaluation of swing-through gait by using model calculation method}

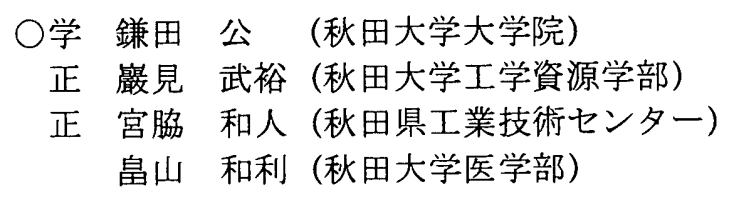

\author{
学 中村真知子 (秋田大学大学院) \\ 島田 洋一（秋田大学医学部） \\ 松永 俊樹 (秋田大学医学部) \\ 佐藤 峰善（秋田大学医学部）
}

K. Kamada, M. Nakamura, Graduate School, Akita University, Tegatagakuentyou1-1, Akita-city, Akita T. Iwami, Akita University

Y. Shimada, T. Mastunaga, K. Hatakeyama and M. Satou, Akita University

K. Miyawaki, Akita Prefectural Industrial Technology Center

Key Words : swing-through gait, Axillary crutch, Lofstrand crutch, C-posture, FES

\section{1. 緒 言}

対麻㾴者の移動手段としては車いすの使用が一般的であ る. しかし, 下肢の筋萎縮や血行障害などの廃用症侯群を予 防するため, 可能であれば起立が推奨され, 長下肢装具と平 行棒などを用いた歩行訓練が行われている. 本グループでは， これまで FES (機能的電気刺激)を用いた対麻浭者の交互歩 行の再建に取り組んできたが，より効率のよい起立歩行とし て, 長下肢装具の代わりに FES を用いて膝支特性を確保した swing-through gait の再建を目指す。この swing-through gait とは, Fig. 1のように両側の杖と両足を交互に大きく振 り出す杖歩行の形態である. 本研究では, ロフストランド杖 と松葉杖による上肢負荷の違い, また, 通常の swing-through gait と C-posture と呼ばれる歩行形態の下肢負荷を比較す る. 負荷の算出法は, 身体を㓮体リンクモデルと筋骨格モデ ルにモデル化することで生体内力を算出し, 結果を比較する ことで実用的な swing-through gaitの条件を検討する.

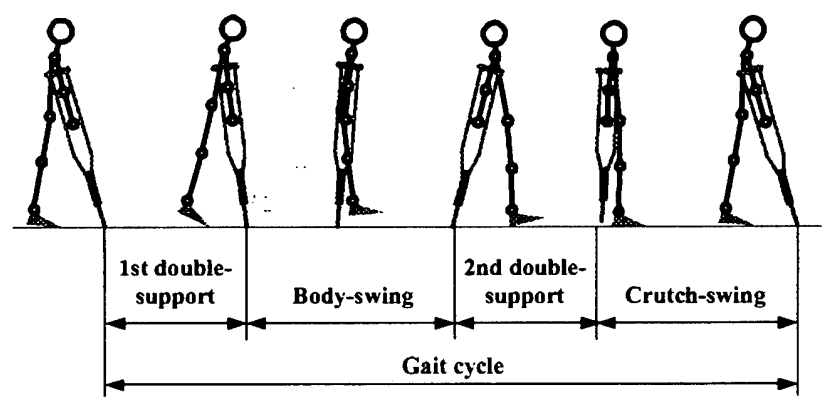

Fig. 1 swing-through gait

\section{2. 解析モテル}

\section{1 间体リンクモデルによる関節トルクの算出}

ロフストランド杖と松葉杖による歩行時の運動特性から， 関節トルクの算出には, Fig. 2 の㓮体リンクモデルを用いた. 図中の矢印は歩行時に身体に加わる外力である. ロフストラ ンド杖の場合は，杖と前腕部が一体となって運動するため, これを 1 つの剛体リンクとし, 杖先と足部が受ける床反力を 外力とした. 一方, 松葉杖の場合はグリップ部のカベクトル を直接計测し, 動力学計算により各関節のトルクを算出した. 日本機械学会東北支部第 40 期秋季講演会講演論文集
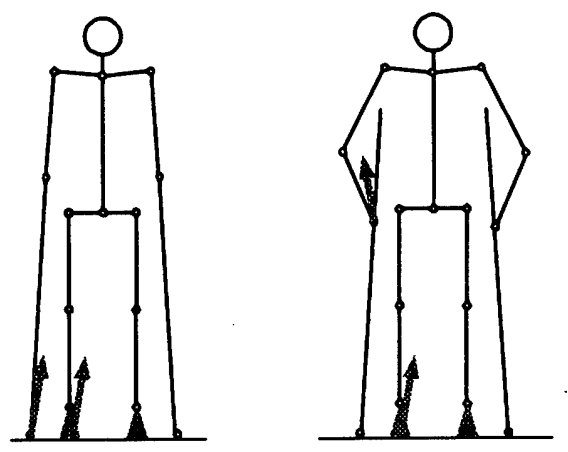

Fig. 2 The link model of lofstrand crutch (a) and axillary crutch (b)

\section{2 笳骨格モデルによる筋弦力, 筋消费エネルギの推定}

筋張力, 筋消費エネルギの推定には, 上肢, 下肢の関節を 駆動する筋として運動に支配的な 19 の筋だけに着目した筋 骨格モデルを用いた(Fig. 3).

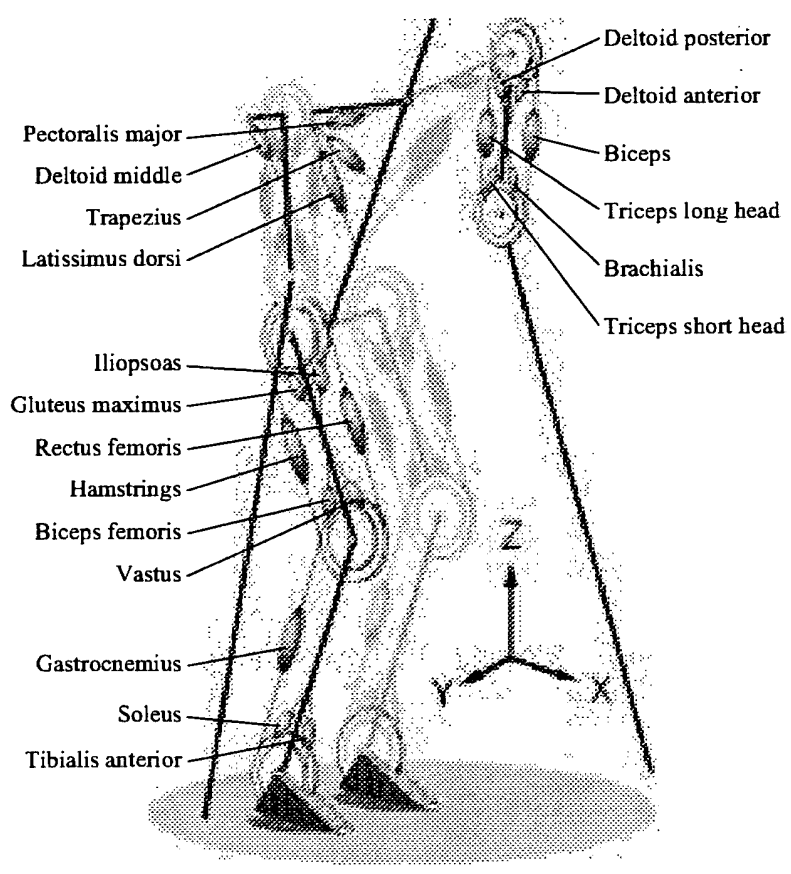

Fig. 3 Muscle skeletal model 
上肢と下肢を駆動する主要な筋の張力は, 関節を中心とし た滑車モデルにより計算した，それぞれの関節における関節 トルクと筋張力の関倸は以下の式となる.

$$
\sum L \cdot F=\tau
$$

$L$ は関節の回転中心から筋付着位置までの長さである. しか し，関節の数より筋の数の方が多いため，(1)式だけでは方 程式の数より未知数が多くなり，筋張力は一意に定まらない。 そこで，各筋の負荷の二乗和が最小になるように，(2)式の ような評価関数 $Z$ を設定し, 最適化手法を用いて算出した.

$$
Z=\Sigma\left(F / F_{\max }\right)^{2}
$$

ここで， $F_{\max }$ は最大筋張力である.

一方，肩甲带を下制する働きの広背筋と僧帽筋の筋張力は 以下の式より求めた.

$$
\begin{aligned}
& F_{L}=0.8 \times n_{s} / \cos \omega_{L} \\
& F_{T}=0.2 \times n_{s} / \cos \omega_{T}
\end{aligned}
$$

$n_{s}$ は肩関節間力, $\omega$ は体幹正中線に対する筋の傾きである.

運動中の筋消費エネルギは，江原らが示す Hill の生理式

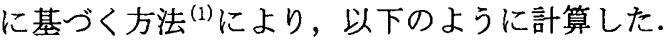

(1) 短縮性収縮の場合 $(v>0)$

単位時間当たりの筇消費エネルギは以下の式となる.

$$
P=F \cdot v+A \cdot v+A \cdot b
$$

ここで， $A, \quad b$ はillの定数である。

（2）等尺性収縮 $(v=0)$ ，伸張性収縮 $(v<0)$ の場合

等尺性收縮の場合も(5)式と同じ仮定が成立する，そのた め， $v=0$ を代入することで(6)式となる．伸張性収縮の場合 においても同じ関係が成立する。

$$
P=A \cdot b
$$

\section{3. 寞 験}

身体運動の計測には，光学式位置計測装置 (PEAK Motus) を用い，身体に加わる外力の計測には，右の杖先と右足部に 加わる床反力を，床反力計（KISTLER 9286）を用いて計測し た.また，松葉杖のグリップから手先に加わる外力は，杖頭 部に組み込んだカ覚センサ（Nitta IFS-67M25A）と，杖先の 床反力計で計測した力ベクトルの差から求めた.

実験では，健常成人男性 15 名において，以下に示す 2 種 類の比較実験を行った.

（1）ロフストランド杖と松葉杖を用いた自由歩行

（2）松葉杖を用いた自由歩行とC-posture

自由歩行とは，被験者が歩行しやすい状態で行った swing-through gaitのことである.C-posture とは，接地時 に体幹を突き出して体重心を前に置くことにより, 床反力が 膝の前を通るようにする姿勢である。これにより外力が溙の 伸展方向に働くため，膝折れを防ぐ効果がある(2). FES を用 いた swing-through gait では，接地時に膝伸展筋の刺激を 繰り返すが，実用的な起立歩行を実現するためには，少しで も筋疲労の少ない歩行形態が望ましい，そこで，下肢の筋疲 労を比較するため，松葉杖を用いた自由歩行とC-posture を 測定した.

\section{4. 結 果}

実験 (1) の結果から上肢の筋消費エネルギを比較する (Fig. 4). 特徵的な違いとして，ロフストランド杖では上腕 三頭筋短頭，上腕三頭筋長頭の消費エネルギが大きく, 松葉 杖では大胸筋の消費エネルギが特に大きい. 大胸筋は筋容量 が非常に大きいため，消費エネルギが大きくても筋疲労は少 なく，安定した歩行といえる，一方，ロフストランド杖では 大胸筋と比べ小さい筋を使っているため，操作性は良いが筋 疲労が大きく安定感が悪いと考えられる. これは実験後の被 験者の意見とも一致していた. 次に，赛験 (2)の結果から下 肢の消費エネルギを比較する (Fig. 5).C-posture では大腿直 筋，広筋の消費エネルギが少ないことから，FES で刺激する 膝伸展筋の筋疲労が少なくてすむことが予想される。

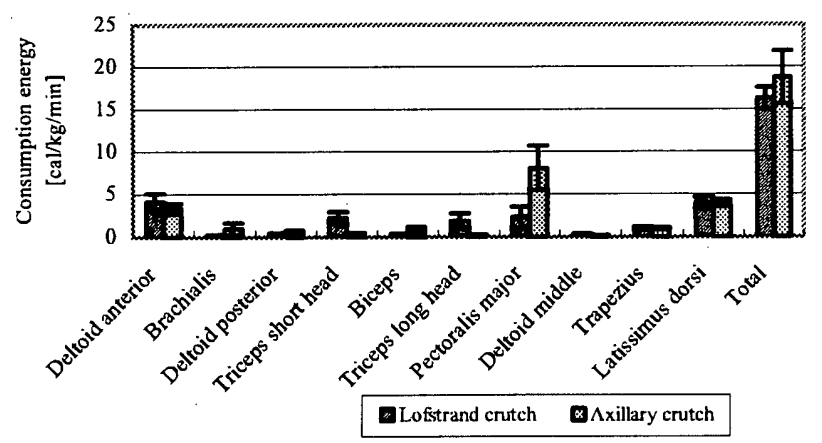

Fig. 4 Comparison of the consumption energy by difference of crutch

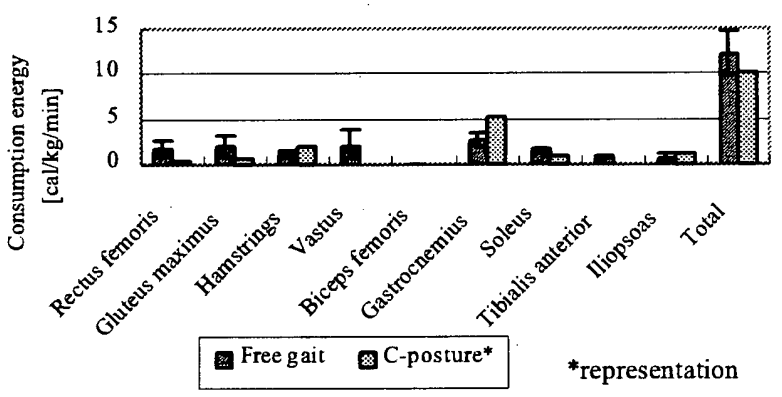

Fig. 5 Comparison of the consumption energy by difference of gait pattern

\section{5. 結 言}

以上の結果から，本研究の目的である FES を用いた実用的 な swing-through gait の実現には、松葉杖を使用した C-posture という条件が適していると考えられる.

\section{参考文献}

（1）江原義弘：筋張力・エネルギー・EMG，第 4 回筋のモデル と筋張力推定テキスト，臨床歩行分析懇談会編， 33-57 (1994)

(2) BW Heller, MH Granat and BJ Andrews : Swing-through gait with free-knees produced by surface functional electrical stimulation, Paraplegia, 34, 8-15 (1996) 